\title{
Acetylsalisylsyre kan forebygge preeklampsi
}

\section{Daglig bruk av acetylsalisylsyre i lave doser fra annet trimester kan fore- bygge preeklampsi hos en del kvinner, og det er ikke negative effekter.}

Preeklampsi er den vanligste og farligste svangerskapskomplikasjonen for mor og barn over hele verden. En rekke risikofaktorer er kjent, men tilstanden er vanskelig å forutsi. En amerikansk forskergruppe har nylig gjort en systematisk gjennomgang av studier om bruk av acetylsalisylsyre i lav

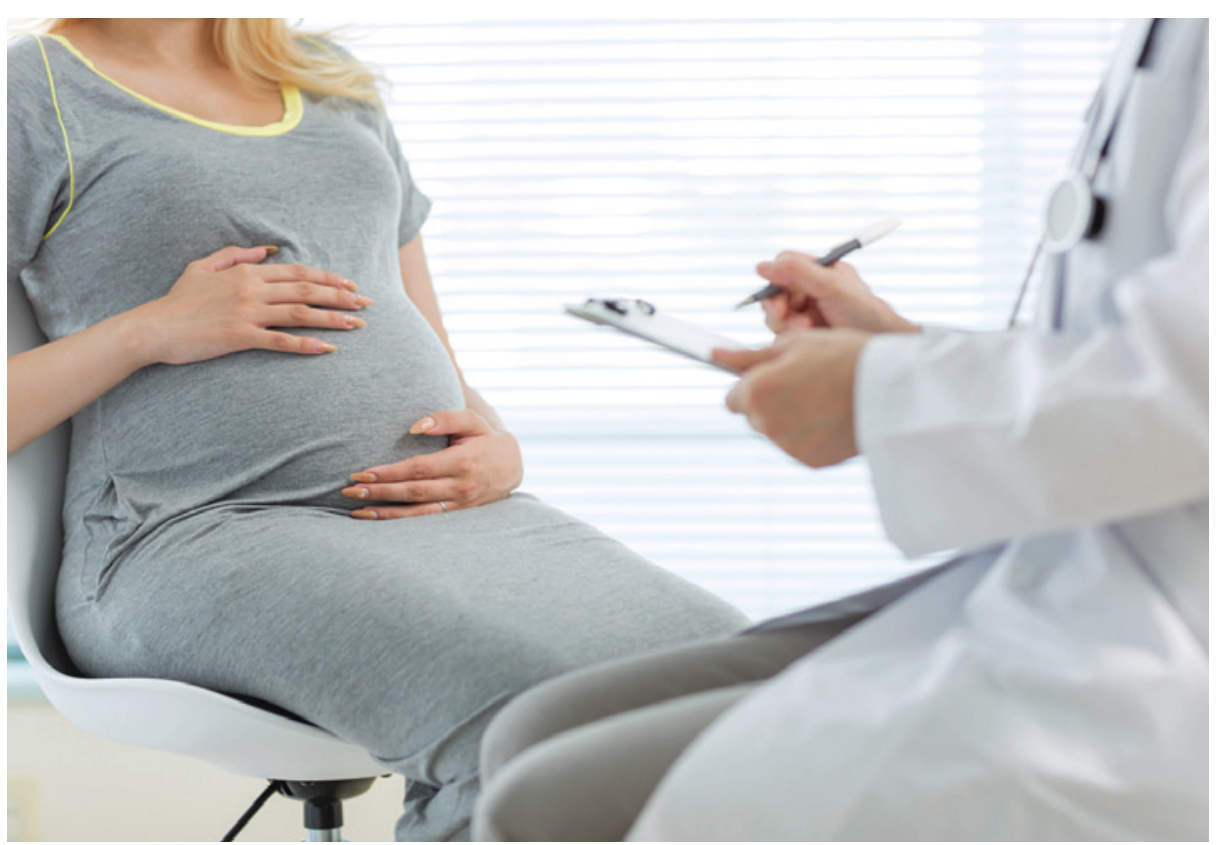

Illustrasjonsfoto: Thinkstockphoto dose for å forebygge sykdom og død ved preeklampsi (1).

21 randomiserte studier med kvinner med forhøyet eller gjennomsnittlig risiko for preeklampsi og to store kohortstudier ble inkludert $i$ analysen. Avhengig av utgangsrisikoen var bruk av acetylsalisylsyre asso-

siert med en absolutt risikoreduksjon på $2-5 \%$ for preeklampsi (relativ risiko 0,76 ; $95 \%$ KI $0,62-0,95$ ), på $1-5 \%$ for intrauterin veksthemming (RR 0,80;95\% KI $0,65-0,99)$ og på $2-4 \%$ for prematur fødsel (RR 0,86; $95 \%$ KI 0,76-0,98). Det ble ikke påvist bivirkninger av betydning, verken for mor eller barn.

- Denne systematiske gjennomgangen bekrefter tidligere funn om en moderat beskyttende effekt av acetylsalisylsyre på preeklampsiutvikling hos omtrent en firedel av kvinner med økt risiko, sier professor Annetine Staff ved Kvinne- og barneklinikken, Oslo universitetssykehus. - Studien kunne ikke vise noen reduksjon i perinatal dødelighet, til tross for redusert preeklampsiforekomst og færre premature forløsninger. Dette kan skyldes at de fleste studier er foretatt i land der mortalitet og morbiditet ved preeklampsi er lav, sier hun.

- Preeklampsi er et syndrom med kompleks patofysiologi, og det er usannsynlig at samme type forebygging vil være like effektivt hos alle gravide. Vi trenger mer kunnskap om hvordan vi bedre kan identifisere risikogruppene, for eksempel gjennom sirkulerende maternelle biomarkører, sier Staff.

\section{Trine B. Haugen}

Tidsskriftet

\section{Litteratur}

1. Henderson JT, Whitlock EP, O'Connor E et al. Lowdose aspirin for prevention of morbidity and mortality from preeclampsia: a systematic evidence review for the U.S. Preventive Services Task Force. Ann Intern Med 2014; 160: 695-703.

\section{AD/HD hos barn etter feberkramper}

\section{Gjentatte episoder med feber- \\ kramper hos barn er assosiert med $ø$ kt risiko for utvikling av AD/HD.}

$\mathrm{AD} / \mathrm{HD}$ (attention deficit/hyperactivity disorder) er en heterogen nevrobiologisk tilstand som gir vansker knyttet til sosiale, emosjonelle og atferdsmessige forhold, med konsekvenser for læring og kognitiv utvikling. Faktorer som kan ha betydning for sammenhengen mellom feberkramper og $\mathrm{AD} / \mathrm{HD}$ er undersøkt i en studie som nylig er publisert i Archives of Disease in Childhood (1). Studien fra Taiwan inkluderte over tusen barn i alderen 6 md. -5 år med diagnosen feberkramper. Dataene ble hentet fra en nasjonal database for perioden 2000-10. Barn med diagnosene AD/HD og hyperkinetisk syndom, epilepsi og kramper, myo- klonier eller kramper (hos nyfødte) ble ekskludert. Studiekohorten ble sammenliknet med en kontrollgruppe ut fra alder, kjønn, urbaniseringsnivå og foreldrenes yrke.

Barn med gjentatte feberkramper hadde signifikant høyere risiko for utvikling av $\mathrm{AD} / \mathrm{HD}$ i løpet av studieperioden enn kontrollgruppen (OR 1,66, $95 \%$ KI 1,27-2,18). Risikoen økte med hyppigheten av registrerte feberkramper. Høy urbaniseringstetthet var også knyttet til høy forekomst av $\mathrm{AD} / \mathrm{HD}$.

- Matchet pasienet-kontroll-design er en god måte å kontrollere for kofunderende faktorer på, sier lege og postdoktorstipendiat Pål Surén ved Folkehelseinstituttet.

- Hovedfunnet, dvs. at barn med feberkramper har større risiko for senere å få en $\mathrm{AD} / \mathrm{HD}$-diagnose er solid, men forfatterne legger kanskje for mye vekt på forskjeller mellom undergruppene. Det er relativt få barn med AD/HD-diagnoser i hver undergruppe, og siden konfidensintervallene er overlappende, bør man være forsiktig i fortolkningen av forskjeller mellom dem, sier han.

- Taiwan har et avansert helsevesen og gode levekår, så studien har overføringsverdi til norske forhold. Slike studier vil også kunne gjøres i Norge, ettersom tilsvarende data finnes i den norske mor-og-barnundersøkelsen og i Norsk pasientregister, sier Surén.

\section{Betty Kalikstad}

Institutt for klinisk medisin

Universitetet i Oslo

\section{Litteratur}

1. Ku YC, Muo CH, Ku CS et al. Risk of subsequent attention deficit-hyperactivity disorder in children with febrile seizures. Arch Dis Child 2014: 99 : $322-6$ 